\title{
SOLIDIFICATION AND SOLID STATE PHASE TRANSFORMATION OF ALLVAC ${ }^{\circledR}$ 718PLUSTM ALLOY
}

\author{
Wei-Di Cao \\ ATI Allvac, an Allegheny Technologies Company, 2020 Ashcraft Avenue, \\ Monroe, NC 28110, USA
}

Keywords: 718Plus, Solidification, Aging, $\delta$ phase

\begin{abstract}
Solidification and solid state transformations of Allvac ${ }^{\circledR} 718$ Plus $^{\mathrm{TM}}$ alloy were studied by modeling and experiment. Solidification behavior was investigated by DTA and SEM/EDS techniques and compared with modeling calculations. Various phases were identified and formation of the cast structure was interpreted on the basis of a pseudo-binary phase diagram developed in this work. The chemistry, crystal structure and growth rate of hardening phases and their precipitation kinetics were studied. Aging behavior and the effect of solution temperature and plastic deformation were addressed. Special attention was paid to $\delta$ phase precipitation. The nature, morphology and formation kinetics of $\delta$ phase were investigated and its effect on mechanical properties are discussed.
\end{abstract}

\section{Introduction}

In recent decades, an effort has been made to develop a Ni-base superalloy that has temperature capability at least $55^{\circ} \mathrm{C}$ higher than that of alloy 718 with 718 -like processability and a cost lower than that of alloys applied at equivalent temperatures such as Waspaloy. As part of this effort, a new alloy, Allvac ${ }^{\mathbb{R}} 718$ Plus $^{\mathrm{TM}}$, was developed at ATI Allvac [1]. The chemistry of this alloy was determined by detailed modeling and experimental studies and the results have been reported [2]. Much experimental work demonstrated that this alloy has excellent mechanical properties up to $704^{\circ} \mathrm{C}$, processability approaching that of alloy 718 and cost lower than alloys such as Waspaloy and René 41 [3-4]. The chemistry of this alloy, together with alloys 718 and Waspaloy is shown in Table I.

Table I. Nominal Chemistry Comparison of Alloys 718Plus ${ }^{\mathrm{TM}}, 718$ and Waspaloy

\begin{tabular}{|c|c|c|c|c|c|c|c|c|c|c|c|}
\hline \multirow{2}{*}{ Alloy } & \multicolumn{10}{|c|}{ Chemistry, wt\% } \\
\cline { 2 - 14 } & $\mathrm{C}$ & $\mathrm{Cr}$ & $\mathrm{Mo}$ & $\mathrm{W}$ & $\mathrm{Co}$ & $\mathrm{Fe}$ & $\mathrm{Nb}$ & $\mathrm{Ti}$ & $\mathrm{Al}$ & $\mathrm{P}$ & $\mathrm{B}$ \\
\hline 718Plus & 0.025 & 18.0 & 2.70 & 1.0 & 9.0 & 10.0 & 5.40 & 0.70 & 1.45 & 0.007 & 0.004 \\
\hline 718 & 0.025 & 18.1 & 2.90 & - & - & 18.0 & 5.40 & 1.00 & 0.45 & 0.007 & 0.004 \\
\hline Waspaloy & 0.035 & 19.4 & 4.25 & - & 13.25 & - & - & 3.00 & 1.30 & 0.006 & 0.006 \\
\hline
\end{tabular}

Like other superalloys, the processing of alloy 718Plus, especially solidification, hot working and heat treatment practices, has to be carefully controlled to generate a desirable microstructure and therefore the required mechanical properties. A thorough understanding on the relationships among processing, microstructure and mechanical properties is very critical to the application of this alloy. This type of study obviously requires many years effort by many researchers, as shown in some highly successful alloys such as 718 . Therefore, only a few relevant topics could 
be addressed in this study and the results must be preliminary in nature. Solidification structure, $\gamma^{\prime} / \gamma^{\prime \prime}$ precipitate state and $\delta$ phase precipitation among others play a very critical role in forming the mechanical properties of this alloy. This paper will concentrate on these issues and briefly introduce the results of relevant studies.

\section{Solidification Behavior}

Solidification structure, including macro-, microsegregation and various eutectic reactions, significantly influence the mechanical properties of wrought products, and the behavior in solidification will determine the size of ingot that can be readily made from this alloy. The behavior during solidification was investigated by modeling calculations, differential thermal analysis (DTA) and detailed SEM/EDS study of the cast structure.

\section{$\underline{\text { Modeling Analysis }}$}

Modeling analysis of the solidification process was conducted, using the JMatPro software tool, on both alloys 718 and 718Plus. A comparison was made of the solidification temperature range, $\mathrm{Nb}$ segregation and carbide formation of both alloys. As shown in Table II, both alloys have similar liquidus, solidus and, therefore, solidification temperature ranges with those of alloy 718 Plus being slightly lower. Segregation of $\mathrm{Nb}$ in alloy 718Plus is actually slightly lower than alloy 718 although both have the same $\mathrm{Nb}$ content. The carbide precipitation in both alloys are also very similar.

Table II. Modeling Results of Solidification Characteristics of Alloys 718Plus ${ }^{\mathrm{TM}}$ and 718

\begin{tabular}{|c|c|c|c|c|c|c|c|}
\hline \multirow{2}{*}{ Alloy } & \multicolumn{2}{|c|}{$\begin{array}{c}\text { Solidification Temperature } \\
{ }^{\circ} \mathrm{C}\end{array}$} & \multicolumn{2}{c|}{ Nb Segregation } & \multicolumn{2}{c|}{ MC Carbide Precipitation } \\
\cline { 2 - 8 } & $\begin{array}{c}\text { Liquidus } \\
\mathrm{T}_{\mathrm{L}}\end{array}$ & $\begin{array}{c}\text { Solidus } \\
\mathrm{T}_{\mathrm{S}}\end{array}$ & $\mathrm{T}_{\mathrm{L}}-\mathrm{T}_{\mathrm{S}}$ & $\begin{array}{c}\text { Partition } \\
\text { Coefficient } \\
\mathrm{K}_{\mathrm{Nb}}\end{array}$ & $\begin{array}{c}\text { Nb in } \\
\text { liquid at } \\
\text { Solidus }\end{array}$ & $\begin{array}{c}\text { Precipitation } \\
\text { Temperature } \\
{ }^{\circ} \mathrm{C}\end{array}$ & $\begin{array}{c}\text { MC at } \\
\text { Solidus }\end{array}$ \\
\hline 718 Plus & 1346 & 1201 & 145 & 0.40 & $13.43 \%$ & 1260 & $0.160 \%$ \\
\hline 718 & 1358 & 1214 & 144 & 0.35 & $15.42 \%$ & 1267 & $0.155 \%$ \\
\hline
\end{tabular}

The freckle tendency of various Ni-base superalloys has been calculated using Rayleigh number criterion [5]. As Figure 1 shows, alloy 718Plus has similar freckle tendency to alloy 718 and 625.

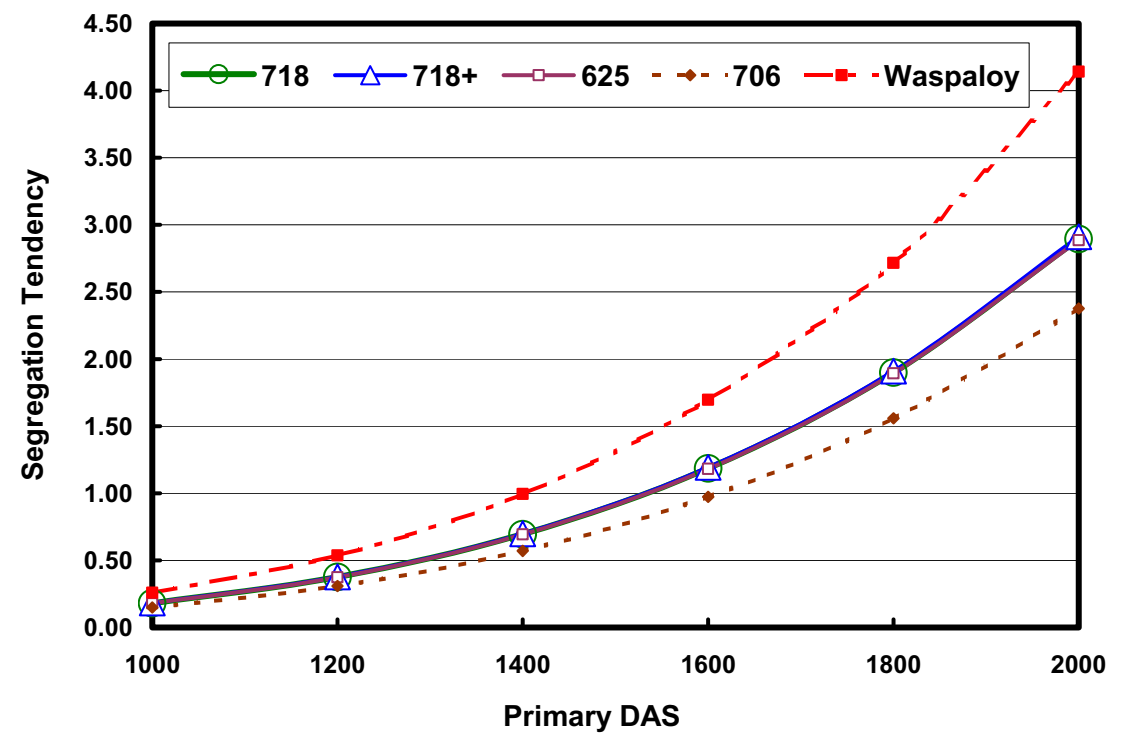

Figure 1. Rayleigh Criterion Segregation Tendency for Various Wrought Ni-Base Alloys. 
Waspaloy has the highest freckle tendency among all alloys calculated. This, coupled with the data in Table II, suggests that the capability of alloy 718Plus for making large size ingot might be similar to that of alloy 718 and better than Waspaloy.

\section{Differential Thermal Analysis (DTA) Study}

To clarify non-equilibrium behavior, a DTA study was conducted on alloy 718Plus. A comparison with data on alloy 718 [6] is made in Table III. It shows that both alloys have quite similar behavior in a non-equilibrium condition. Both alloys showed a Laves eutectic reaction at similar temperatures during solidification. This eutectic could be eliminated by long time homogenization because Laves eutectic reaction did not show up in the DTA on-heating cycle of homogenized material and was only seen in the on-cooling solidification cycle. It appears that DTA gives a higher liquidus for alloy 718 Plus and higher solidus for both alloys, which means the solidification range drops from $145^{\circ} \mathrm{C}$ (modeling) to $88^{\circ} \mathrm{C}$ (DTA) for alloy 718 Plus and from $144^{\circ} \mathrm{C}$ (modeling) to $110^{\circ} \mathrm{C}$ (DTA) for alloy 718 .

Table III. Critical Phase Transformation Temperatures of Alloys 718Plus ${ }^{\mathrm{TM}}$ and 718

\begin{tabular}{|c|c|c|c|c|c|c|}
\hline \multirow{2}{*}{$\begin{array}{c}\text { Phase } \\
\text { Transformation }\end{array}$} & \multicolumn{2}{|c|}{ Modeling } & \multicolumn{2}{c|}{ DTA } & \multicolumn{2}{c|}{ Metallography } \\
\cline { 2 - 7 } & $\begin{array}{c}718 \text { Plus } \\
{ }^{\circ} \mathrm{C}\end{array}$ & $\begin{array}{c}718 \\
{ }^{\circ} \mathrm{C}\end{array}$ & $\begin{array}{c}718 \text { Plus } \\
{ }^{\circ} \mathrm{C}\end{array}$ & $\begin{array}{c}718 \\
{ }^{\circ} \mathrm{C}\end{array}$ & $\begin{array}{c}718 \text { Plus } \\
{ }^{\circ} \mathrm{C}\end{array}$ & $\begin{array}{c}718 \\
{ }^{\circ} \mathrm{C}\end{array}$ \\
\hline Liquidus & 1346 & 1358 & 1353 & 1345 & - & - \\
\hline MC Eutectic & 1261 & 1246 & 1292 & 1286 & - & - \\
\hline Solidus & 1201 & 1214 & 1265 & 1235 & - & 1230 \\
\hline Laves Eutectic & - & - & 1173 & 1167 & - & 1165 \\
\hline$\delta$ Solvus & 1065 & 1027 & - & - & $1002-1018$ & $996-1015$ \\
\hline$\gamma^{\prime}$ Solvus & 995 & 909 & 963 & 936 & $954-982$ & - \\
\hline$\gamma^{\prime \prime}$ Solvus & 968 & 946 & - & - & - & - \\
\hline
\end{tabular}

\section{$\underline{\text { As-Cast Microstructure and Pseudo-Binary Phase Diagram }}$}

As-cast microstructure of a 500-mm VIM/VAR ingot is shown in Figure 2. It consists of a dendrite structure with $\mathrm{Nb}$-Ti carbide or carbo-nitride eutectics and two types of Laves eutectics, very similar to that of alloy 718. A detailed SEM/EDS study was conducted to identify the phases in cast structure and the results are listed in Table IV. Metallographic analysis showed that there are less Laves eutectics in alloy 718Plus than in alloy 718 .

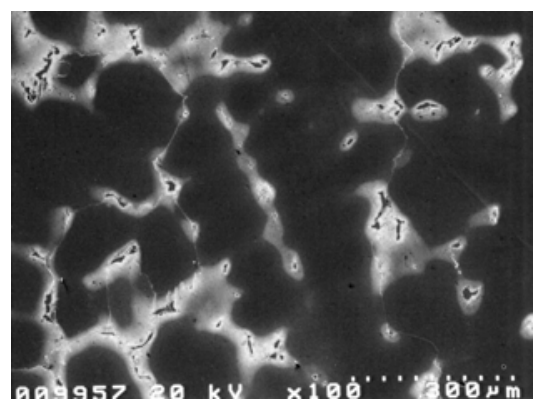

(a)

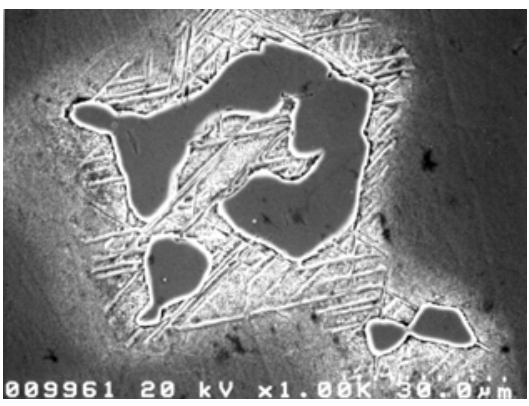

(b)

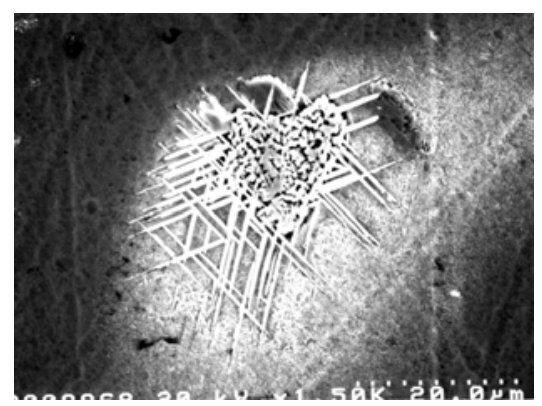

(c)

Figure 2. As-Cast Microstructure of Alloy 718Plus ${ }^{\mathrm{TM}}$ (a) As-Cast Structure, (b) Laves Eutectics - I and (c) Laves Eutectics - II. 
Table IV. Chemistry of Laves and MC Carbides in Alloys 718 and 718Plus ${ }^{\mathrm{TM}}$

\begin{tabular}{|c|c|c|c|c|c|c|c|c|c|c|c|}
\hline \multirow{2}{*}{ Phase } & \multirow{2}{*}{ Alloy } & \multirow{2}{*}{ Method } & \multicolumn{9}{|c|}{ Chemistry (Metal elements only), wt $\%$} \\
\hline & & & $\mathrm{Ni}$ & $\mathrm{Co}$ & $\mathrm{Cr}$ & $\mathrm{Fe}$ & Mo & $\mathrm{W}$ & $\mathrm{Nb}$ & Al & $\mathrm{Ti}$ \\
\hline \multirow[b]{2}{*}{ Laves } & 718 & EDS & 39.5 & - & 13.5 & 13.2 & 5.8 & - & 26.5 & 0.3 & 0.9 \\
\hline & $\begin{array}{l}718 \\
\text { Plus }\end{array}$ & EDS & 35.2 & 9.4 & 11.8 & 6.2 & 5.6 & 1.1 & 29.7 & 0.3 & 0.6 \\
\hline \multirow{6}{*}{$\mathrm{MC}$} & \multirow{3}{*}{718} & Modeling & 0 & - & 0.02 & - & 0.2 & - & 95.9 & 0 & 2.9 \\
\hline & & $\begin{array}{l}\text { EDS Nb- } \\
\text { enriched) }\end{array}$ & 3.3 & - & 1.7 & 1.2 & 3.4 & - & 86.3 & 0 & 7.4 \\
\hline & & $\begin{array}{l}\text { EDS (Ti- } \\
\text { enriched) }\end{array}$ & 1.4 & - & 0.7 & 0.8 & 0.7 & - & 32.6 & 0 & 63.1 \\
\hline & \multirow{3}{*}{$\begin{array}{l}718 \\
\text { Plus }\end{array}$} & Modeling & 0 & 0 & 0.06 & 0 & 0.3 & 0.1 & 96.1 & 0 & 3.2 \\
\hline & & $\begin{array}{l}\text { EDS Nb- } \\
\text { enriched) }\end{array}$ & 2.6 & 0.5 & 0.8 & 0.6 & 0.8 & 0.5 & 81.1 & 0 & 13.1 \\
\hline & & $\begin{array}{l}\text { EDS (Ti- } \\
\text { enriched) }\end{array}$ & 3.6 & 0.6 & 1.7 & 0.7 & 0.1 & 0.2 & 23.3 & 0 & 69.7 \\
\hline
\end{tabular}

In order to understand the formation of cast structure better, extensive EDS work was carried out to construct a pseudo-binary phase diagram illustrated in Figure 3. The solid lines in this figure illustrate the approximate equilibrium borderlines and the dotted lines at the left part of the diagram show non-equilibrium borderlines at actual solidification conditions. The formation of Laves eutectics and its elimination by homogenization can be easily understood from this figure. Compared to similar published figures [7,8] and our own results for alloy 718, less Laves eutectics in alloy 718Plus can be explained. Less Laves phase in this alloy may also be associated with lower iron content.

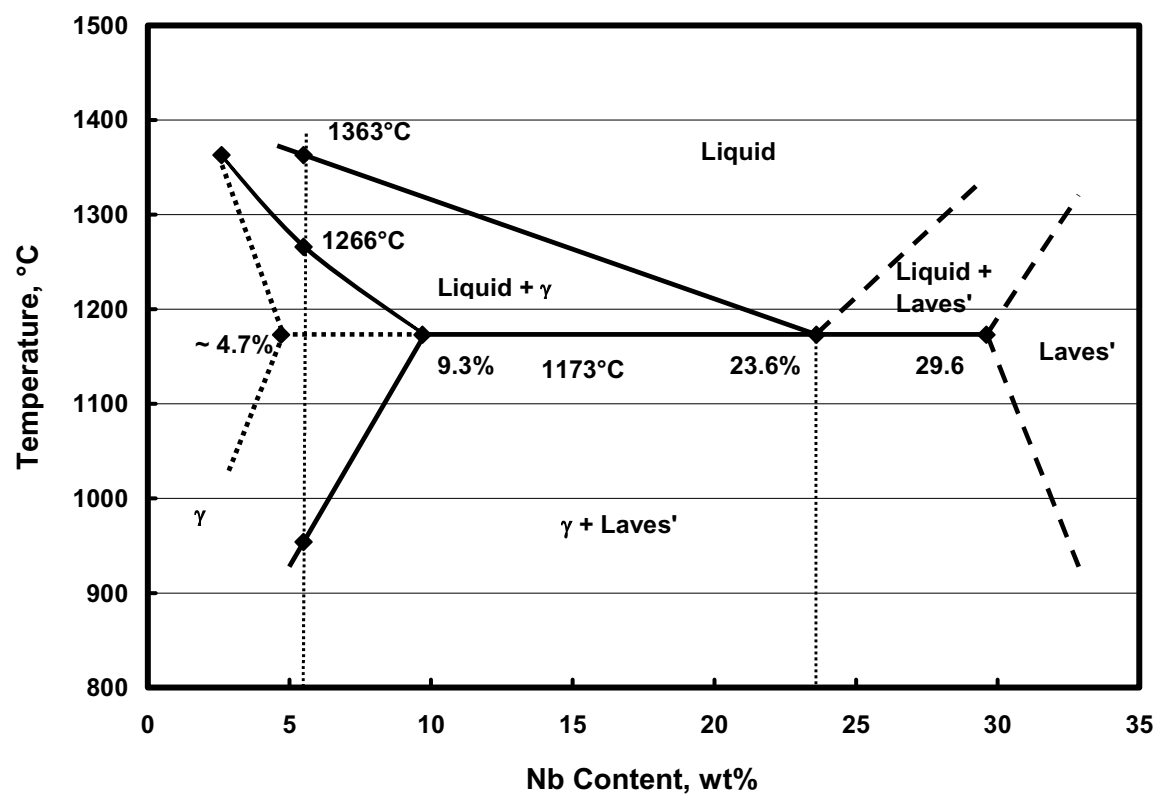

Figure 3. Pseudo-Binary Phase Diagram of Alloy 718Plus ${ }^{\mathrm{TM}}$

\section{Hardening Precipitates and Aging Behavior}

As reported in ref. [2], alloy 718Plus is predominantly strengthened by $\gamma$ ' phase in contrast with alloy 718 strengthened mainly by $\gamma^{\prime \prime}$ phase. Therefore, the precipitation hardening behavior of alloy 718Plus would be different from alloy 718. The nature of hardening phases, their precipitation kinetics, and growth and transformation of precipitates during thermal exposure 
was studied by modeling and various experimental techniques. The aging process and the effect of solution temperature and plastic deformation were also investigated.

\section{Precipitation Hardening Phases}

The modeling results of precipitation hardening phases are listed in Table V. It is obvious that the predominant hardening phase in this alloy is $\gamma^{\prime}$ phase, and its quantity ranges from $19.7 \%$ to $23.2 \%$, depending on the quantity of $\delta$ phase. The $\gamma$ " phase does not exceed $6.64 \%$.

Table V. Modeling Results of Hardening Phases in Alloy $718 \mathrm{Plus}^{\mathrm{TM}}\left(650^{\circ} \mathrm{C}\right)$

\begin{tabular}{|c|c|c|c|c|c|c|c|c|c|c|c|c|}
\hline & \multirow{2}{*}{ Phase } & \multirow{2}{*}{$\begin{array}{c}\text { Solvus } \\
{ }^{\circ} \mathrm{C} \\
\end{array}$} & \multicolumn{9}{|c|}{ Chemistry, wt $\%$} & \multirow{2}{*}{$\begin{array}{c}\text { Content } \\
\text { wt } \%\end{array}$} \\
\hline & & & $\mathrm{Ni}$ & $\mathrm{Co}$ & $\mathrm{Cr}$ & $\mathrm{Fe}$ & Mo & $\mathrm{W}$ & $\mathrm{Nb}$ & $\mathrm{Al}$ & $\mathrm{Ti}$ & \\
\hline \multirow[b]{2}{*}{$\gamma$} & With $\delta$ & 995 & 72 & 3.7 & 0.9 & 1.1 & 0.4 & 0.9 & 11.6 & 5.9 & 3.5 & 19.7 \\
\hline & $\begin{array}{c}\delta \\
\text { suspended }\end{array}$ & 1002 & 71 & 3.9 & 0.9 & 1.0 & 0.3 & 0.8 & 13.8 & 5.4 & 3.0 & 23.2 \\
\hline$\gamma "$ & $\begin{array}{c}\delta \\
\text { suspended }\end{array}$ & 968 & 60 & 5.8 & 0.3 & 0.3 & 0.8 & - & 32.0 & 0.5 & 0.4 & 6.64 \\
\hline
\end{tabular}

The chemistry and quantity of precipitates in alloy 718Plus were analyzed by X-ray diffraction (XRD) of residual obtained from electrolytic extraction and separation [9], and the results are summarized in Table VI.

Table VI. XRD Results of Precipitation Hardening Phases in Alloy 718Plus ${ }^{\mathrm{TM}}$

\begin{tabular}{|c|c|c|c|c|c|c|c|c|c|c|c|c|}
\hline \multirow[t]{2}{*}{ Precipitates* } & \multicolumn{2}{|c|}{$\begin{array}{c}\text { Crystal } \\
\text { Structure }\end{array}$} & \multicolumn{9}{|c|}{ Chemistry, wt $\%$} & \multirow{2}{*}{$\begin{array}{c}\text { Conten } \\
\text { at } 20^{\circ} \mathrm{C} \\
\text { wt } \%\end{array}$} \\
\hline & Lattice & $\mathrm{a}, \mathrm{A}^{\circ}$ & $\mathrm{Ni}$ & $\mathrm{Co}$ & $\mathrm{Cr}$ & $\mathrm{Fe}$ & Mo & $\mathrm{W}$ & $\mathrm{Nb}$ & $\mathrm{Al}$ & $\mathrm{Ti}$ & \\
\hline$\gamma^{\prime}\left(+\right.$ Few $\left.\gamma^{\prime \prime}\right)$ & FCC & 3.62 & 69 & 3.0 & 3.2 & 1.4 & 0.5 & 0.6 & 14.8 & 4.8 & 2.6 & 20.9 \\
\hline
\end{tabular}

* Sample was heat-treated at $954^{\circ} \mathrm{C} \times 1 \mathrm{hr}, \mathrm{AC}+788^{\circ} \mathrm{C} \times 2 \mathrm{hrs}, 55^{\circ} \mathrm{C} / \mathrm{h}$ to $650^{\circ} \mathrm{C} \mathrm{x} 8 \mathrm{hrs}, \mathrm{AC}$. Microstructure contains $<0.5 \% \delta$ phase. $\gamma^{\prime \prime}$ phase cannot be detected.

This work also confirmed that the predominant hardening phase in this alloy is $\gamma^{\prime}$ phase, and the total content of hardening precipitates is about $21 \%$, slightly lower than that obtained from modeling. The chemistries of precipitates from modeling analysis and experiment are very similar, and $\gamma^{\prime}$ phase in this alloy contains high $\mathrm{Nb}$ and $\mathrm{Al}$ with a high $\mathrm{Al} / \mathrm{Ti}$ ratio, which is very different from $\gamma^{\prime}$ phase in Waspaloy. This chemistry may be the root cause of the unique precipitation behavior and strengthening effect of this alloy. The morphology of precipitates of this alloy is shown in Figure 4. The majority of precipitates have a near-spherical shape, a characteristic of $\gamma^{\prime}$ phase particles and no disk-shaped $\gamma^{\prime \prime}$ phase particles were seen. A middle layer can be identified in some particles, especially in the dark field image. It is not clear if this is a $\gamma$ " phase layer or $\delta$ phase layer transformed from $\gamma^{\prime}$ phase.

\section{$\underline{\text { Precipitation Kinetics }}$}

A TTT curve of $\gamma^{\prime}$ and $\gamma^{\prime \prime}$ phases was calculated by JMatPro, as shown in Figure 5, which also shows the TTT curve of $\gamma^{\prime} / \gamma^{\prime \prime}$ precipitation determined by hardness measurement on isothermal annealed samples [10]. It can be seen that the precipitation rate of $\gamma^{\prime}$ phase is faster than $\gamma^{\prime \prime}$ phase in this alloy, as it is in alloy 718. Therefore, alloy 718Plus will have faster precipitation kinetics than alloy 718. Gamma prime phase precipitation in this alloy is much slower than Waspaloy however, which has a very high $\gamma^{\prime}$ phase precipitation rate. 


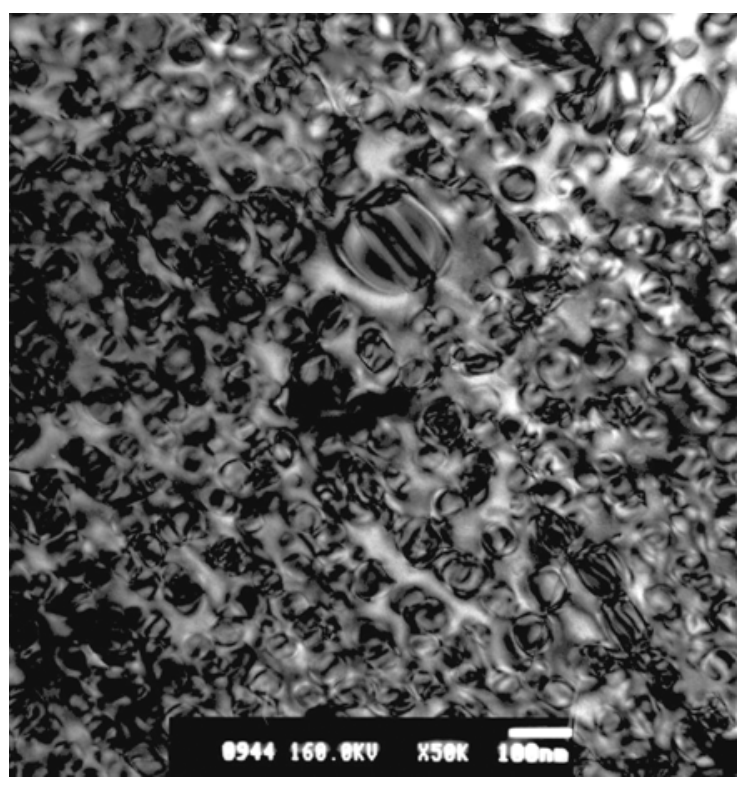

(a) Bright Field

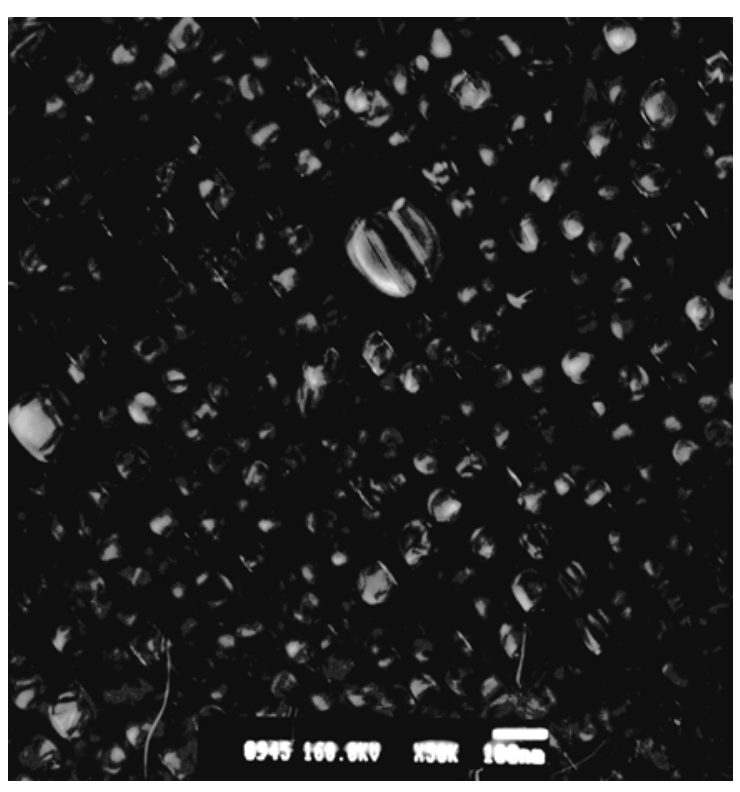

(b) Dark Field

Figure 4. TEM Structure of Precipitation Hardening Phase Particles in Alloy 718Plus ${ }^{\mathrm{TM}}$.

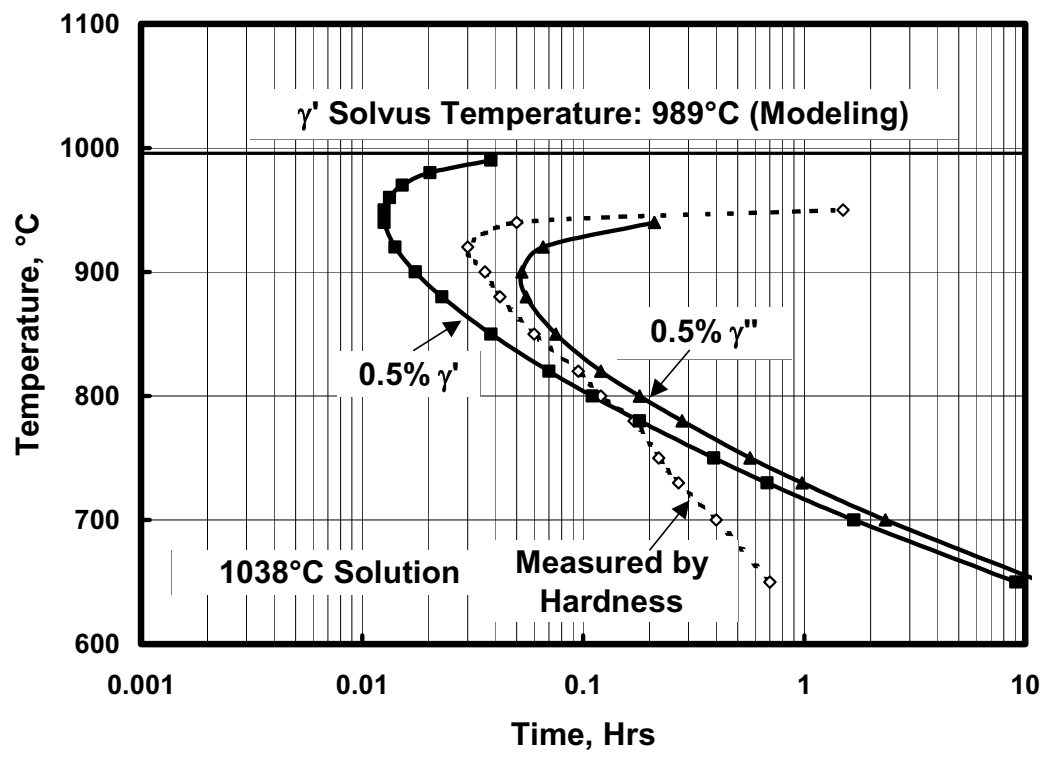

Figure 5. TTT Curves of $\gamma^{\prime}$ and $\gamma^{\prime \prime}$ Precipitation in Alloy 718Plus ${ }^{\mathrm{TM}}$ Generated by Modeling (Solid Line) and Experiment (Dash Line).

The differences in precipitation kinetics are clearly revealed in Figure 6 where the initial age hardening of three alloys is shown. It is clear that the precipitation-hardening rate of alloy 718Plus is right in between those of alloy 718 and Waspaloy. The slower precipitation rate of $\gamma^{\prime}$ phase in alloy 718Plus than in Waspaloy is probably related to its high $\mathrm{Nb}$ content which has a much slower diffusion rate.

\section{Hardening Effect - Aging Behavior}

It has been concluded from previous work that $\gamma^{\prime}$ phase in alloy 718Plus has a higher strengthening effect than $\gamma^{\prime}$ phase in Waspaloy and weaker than $\gamma^{\prime \prime}$ phase in alloy 718. No attempt is made in this paper to explore the $\gamma^{\prime}$ phase strengthening mechanism in alloy 718Plus although it might 


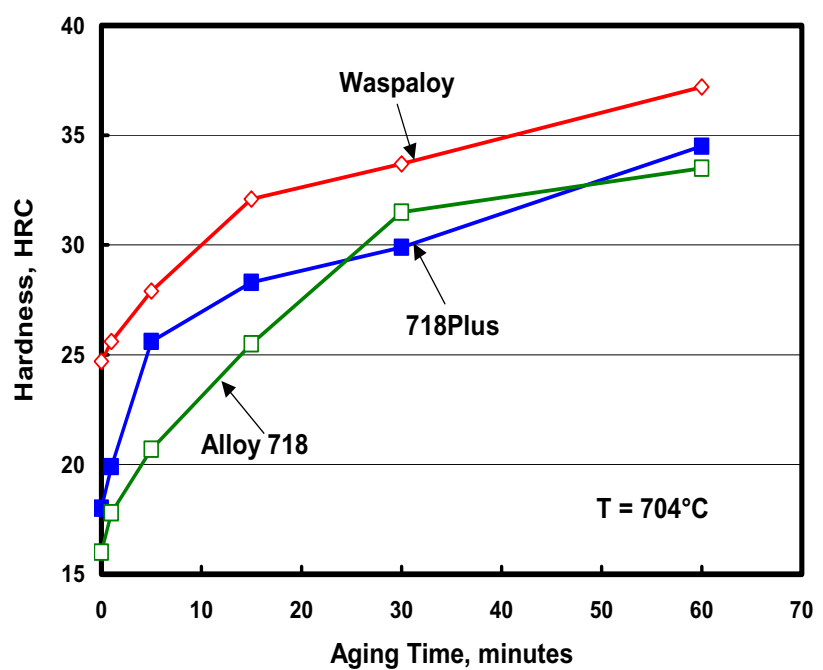

(a)

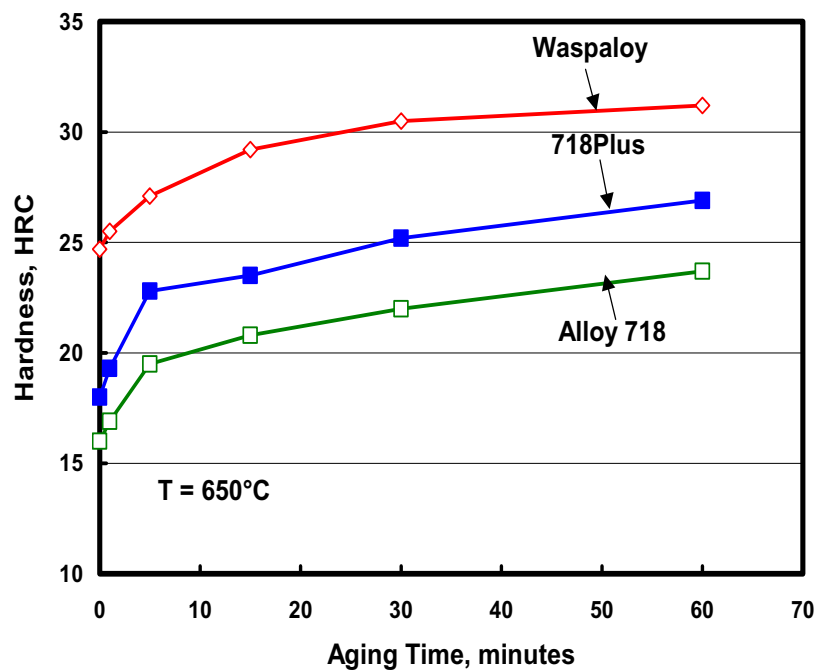

(b)

Figure 6. Aging Curves of Alloy 718Plus ${ }^{\mathrm{TM}}$ in Comparison with Alloys 718 and Waspaloy at (a) $650^{\circ} \mathrm{C}$ and (b) $704^{\circ} \mathrm{C}$.

relate to higher stacking fault energy and higher misfit in comparison with Waspaloy [2]. Recent work at Allvac demonstrated that many factors, especially dislocation substructure, have a significant influence on aging behavior of this alloy. Figure 7 shows the effect of solution temperature on aging process of as-forged alloy 718Plus bars. The peak aged hardness decreased and shifted to longer aging time as solution temperature increased. This behavior may not entirely come from the increase in grain size at higher solution temperature but may also relate to the change in dislocation substructure with increasing temperature.

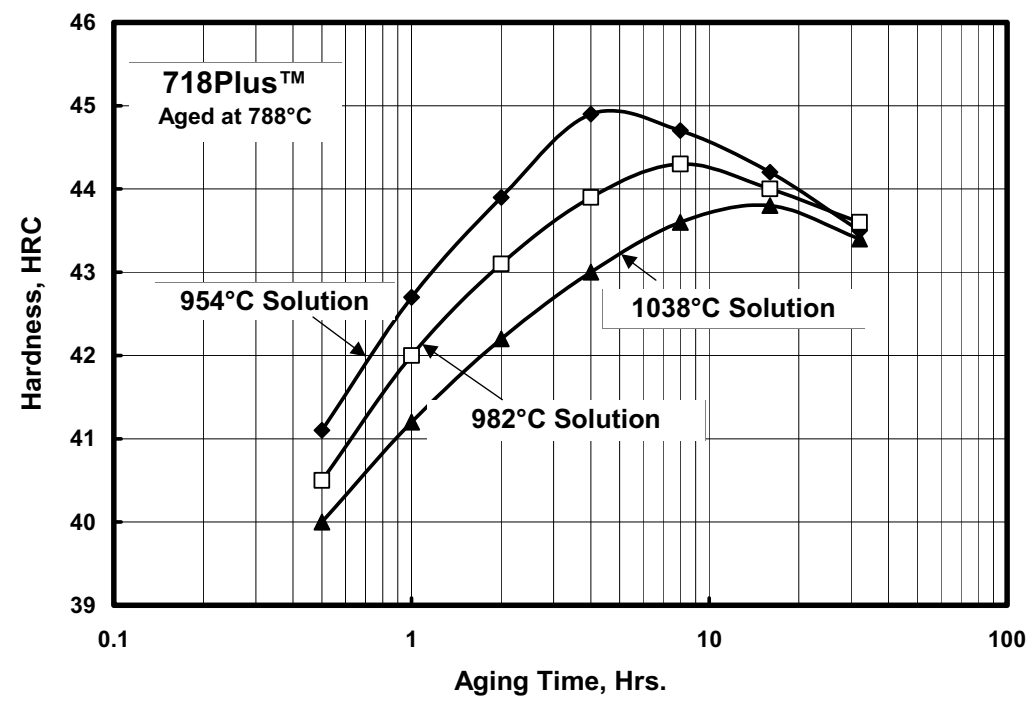

Figure 7. Hardness as a Function of Aging Time in Alloy 718Plus ${ }^{\mathrm{TM}}$ Solution Treated at Different Temperatures.

The effect of dislocation substructure is most clearly revealed in the effect of cold working on aging process, see Figure 8. Cold working prior to aging significantly increased peak aged hardness and accelerated the aging process. All these results demonstrate that plastic deformation could be effectively coupled with the aging process to further improve mechanical properties of this alloy. For example, recent work demonstrated that direct aging could significantly improve the mechanical properties of this alloy [11]. 


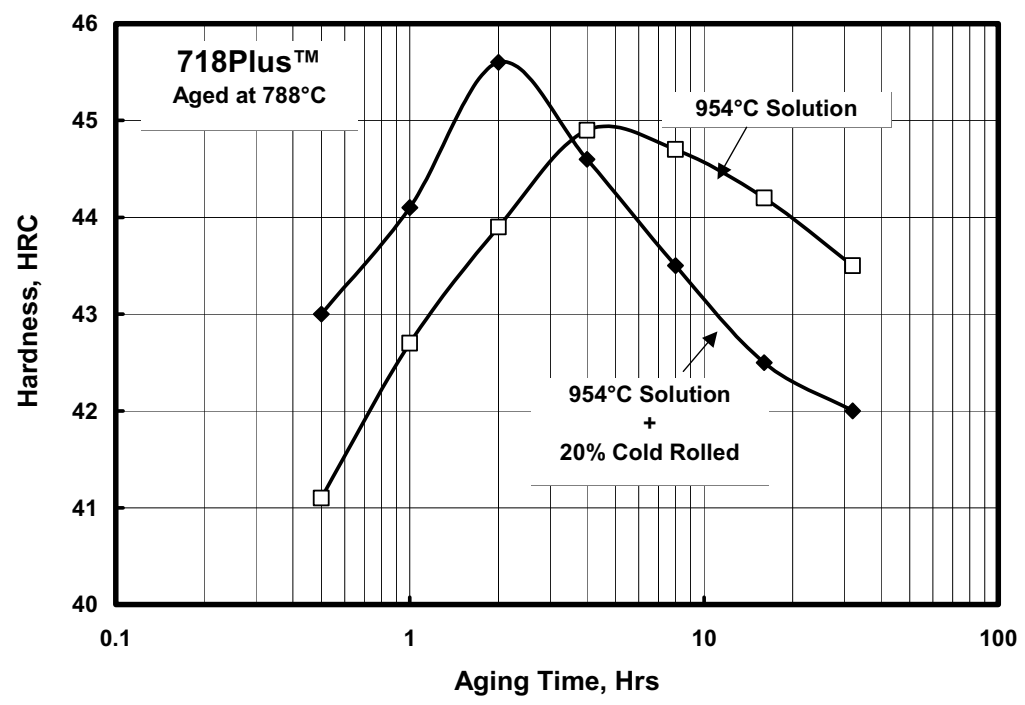

Figure 8. Aged Hardening of Alloy 718Plus ${ }^{\mathrm{TM}}$ Subjected to Cold Working after Solution.

\section{Growth and Transformation of $\gamma^{\prime}$ Phase Particles}

Thermal stability of Ni-base superalloys is controlled by growth and transformation of precipitate particles. A study was conducted to compare the behavior of alloys 718, Waspaloy and 718Plus. Figure 9 shows the modeling result of precipitate particle growth. Some experimental results on particle growth measured by TEM are also included in this figure and there is a reasonable good consistency between calculation and experiment. It can be seen that the growth of $\gamma^{\prime}$ phase in alloy 718Plus has the lowest rate among three alloys, implying that this alloy may have the highest stability in terms of particle growth.

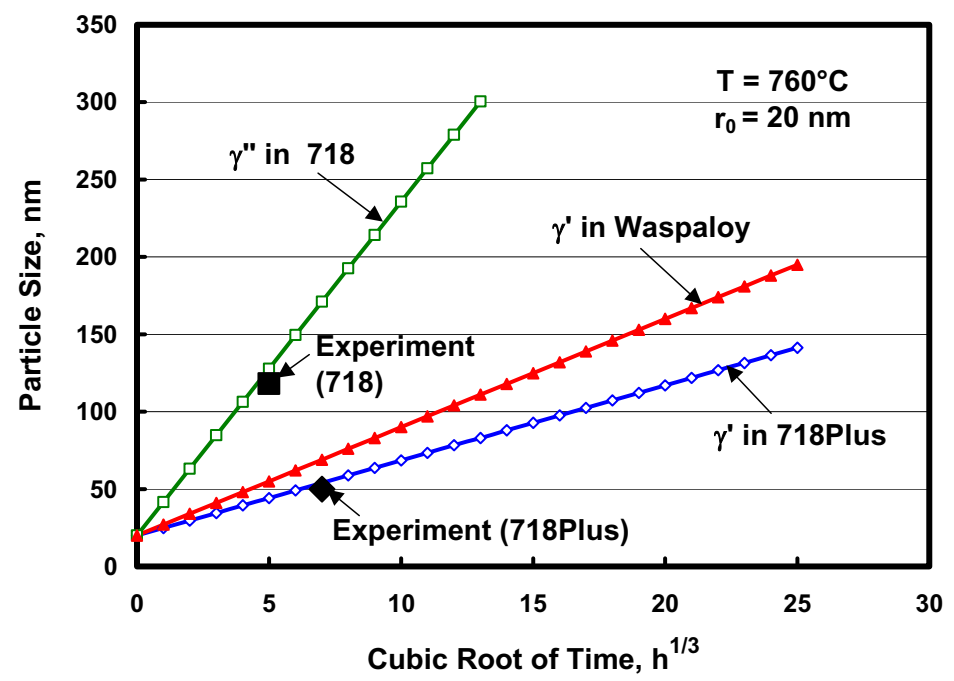

Figure 9. Growth of Hardening Phase Particles in Alloys 718Plus ${ }^{\mathrm{TM}}, 718$ and Waspaloy as Determined by Modeling and Experiment.

It is well known that the transformation of $\gamma^{\prime \prime}$ phase into stable $\delta$ phase plays a decisive role in loss of thermal stability of alloy 718 at high temperature and stable $\gamma^{\prime}$ phase gives Waspaloy much higher thermal stability. The predominant strengthening phase in alloy 718Plus is $\gamma^{\prime}$ phase and this alloy should have high thermal stability. However, it was experimentally proven that the $\gamma^{\prime}$ phase in alloy 718Plus can also transform into $\delta$ phase, but at a rate much slower than that of $\gamma^{\prime \prime}$ phase in alloy 718. Figure 10 compares the microstructures of alloys 718 and 718Plus after thermal exposure. Extensive $\delta$ phase formation occurred in alloy 718 , but no noticeable change 
in $\delta$ phase structure was seen in alloy 718Plus. Slow transformation of $\gamma^{\prime}$ to $\delta$ phase in combination with slow growth rate of $\gamma^{\prime}$ particles makes alloy 718Plus have thermal stability similar to Waspaloy and much better than alloy 718. The detailed mechanism of $\gamma^{\prime}$ to $\delta$ phase transformation in this alloy is not yet clear and requires further study.

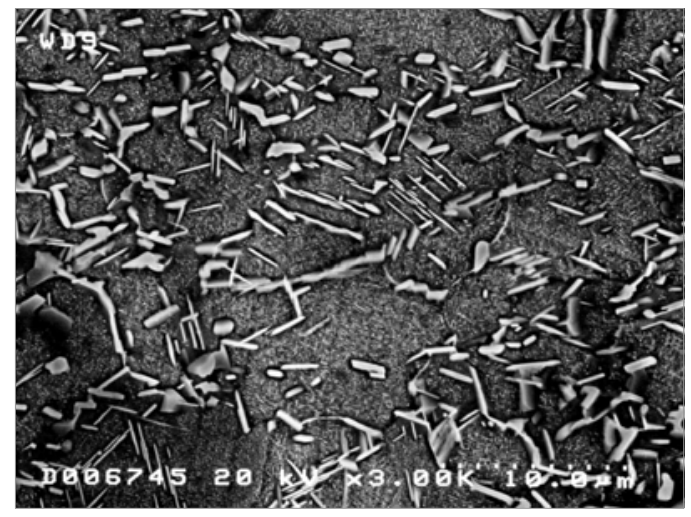

718

Exposed at $704^{\circ} \mathrm{C}$ for $1000 \mathrm{hrs}$.

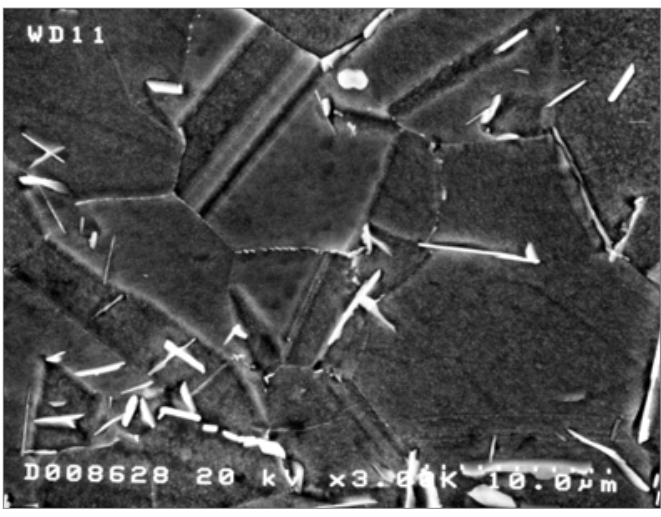

718 Plus

Exposed at $704^{\circ} \mathrm{C}$ for $1000 \mathrm{hrs}$.

Figure 10. Formation of $\delta$ Phase in Alloys 718 and 718 Plus $^{\mathrm{TM}}$.

\section{$\delta$ Phase Precipitation}

Evidence has shown that $\delta$ phase precipitation during hot working and subsequent heat treatment is a very important factor in determining the performance of this alloy. The quantity and morphology of $\delta$ phase exerts a significant effect on strength, rupture/creep life, hold-time fatigue, hot ductility and stress rupture notch behavior.

\section{Delta Phase in Alloy 718Plus}

The solvus temperature, chemistry and structure of $\delta$ phase in alloy 718 Plus have been studied by modeling, XRD and TEM/SAD techniques. The results are summarized in Table VII. It seems that alloys 718 and 718Plus have almost the same $\delta$ solvus temperature, but the solvus determined by modeling is significantly higher than experimental results. There is a significant difference in the chemistry of $\delta$ phase between modeling and experimental results. TEM/EDS work conducted in ref [9] indicates that other than $\delta$ phase, there may be a new phase $\mathrm{Ni}_{3}\left(\mathrm{Nb}_{0.5} \mathrm{Al}_{0.5}\right)$ with a $\mathrm{HCP}$ structure in this alloy. Its chemistry and morphology are very similar to $\delta$ phase and it is difficult to distinguish one from the other. More work is needed to clarify this issue.

Table VII. Delta Phase in Alloys 718Plus ${ }^{\mathrm{TM}}$ and 718

\begin{tabular}{|c|c|c|c|c|c|c|c|c|c|c|c|c|}
\hline \multirow{2}{*}{ Alloy } & & \multirow{2}{*}{ Lattice } & \multirow{2}{*}{$\begin{array}{c}\text { Solvus } \\
{ }^{\circ} \mathrm{C}\end{array}$} & \multicolumn{9}{|c|}{ Chemistry, wt $\%$} \\
\hline & & & & $\mathrm{Ni}$ & $\mathrm{Co}$ & $\mathrm{Cr}$ & $\mathrm{Fe}$ & Mo & $\mathrm{W}$ & $\mathrm{Nb}$ & $\mathrm{Al}$ & $\mathrm{Ti}$ \\
\hline \multirow[b]{2}{*}{$\begin{array}{l}718 \\
\text { Plus }\end{array}$} & Modeling & - & 1065 & 61.4 & 5.1 & 0.2 & 0.2 & 0.6 & - & 31.5 & 0.7 & 0.4 \\
\hline & XRD & $\begin{array}{c}\mathrm{D}_{\mathrm{a}}+ \\
\mathrm{HCP} \\
(?)\end{array}$ & $\begin{array}{c}1002- \\
1018\end{array}$ & 65.1 & 4.6 & 1.0 & 1.4 & 1.2 & 0.5 & 20.1 & 2.7 & 3.5 \\
\hline \multirow{2}{*}{718} & Modeling & - & 1027 & 66.1 & - & 0.3 & 0.5 & 0.8 & - & 30.3 & 0.2 & 1.8 \\
\hline & XRD & $\mathrm{D}_{\mathrm{a}}$ & $\begin{array}{l}996- \\
1015\end{array}$ & 64.4 & - & 3.4 & 5.3 & 2.2 & - & 20.4 & 0.8 & 3.0 \\
\hline
\end{tabular}




\section{$\underline{\text { Precipitation Kinetics }}$}

Temperature dependency of $\delta$ phase quantity in this alloy was determined by modeling and isothermal annealing experiment. As Figure 11 shows, the equilibrium quantity of $\delta$ phase decreases as temperature increases and eventually dissolves into the $\gamma$-matrix at its solvus temperature. Modeling and experiment both show a similar trend, but with significant quantitative differences.

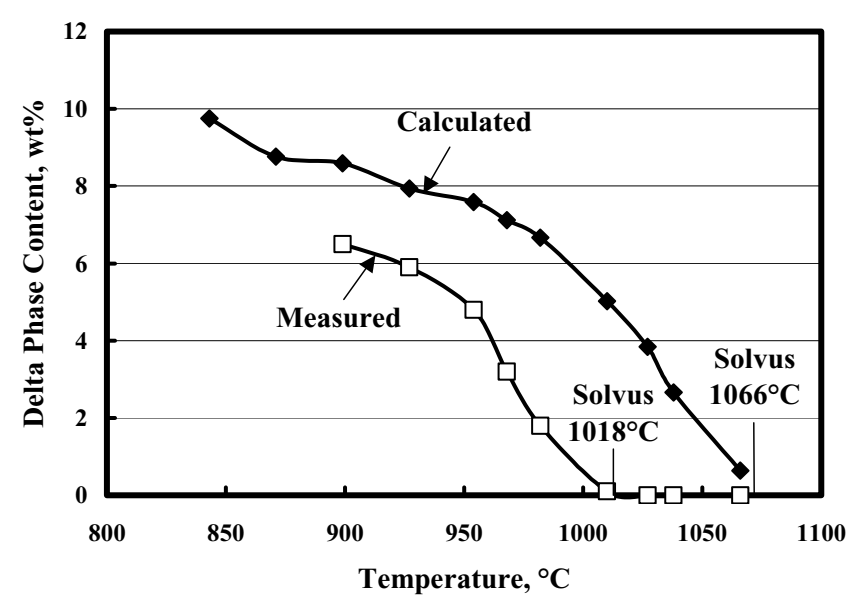

Figure 11. Delta Phase Content as a Function of Heating Temperature.

The TTT curve of $\delta$ phase precipitation obtained by modeling and by experiment on super-solvus $\left(1038^{\circ} \mathrm{C}\right)$ treated alloy [10] is shown in Figure 12. It seems that $\delta$ phase precipitation at grain boundaries is faster than the modeling prediction, but precipitation at other locations is sluggish. Since $\delta$ phase precipitation temperature coincides with typical solution temperature in this alloy, it would be very interesting to study the $\delta$ phase formation of hot worked material during solution treatment.

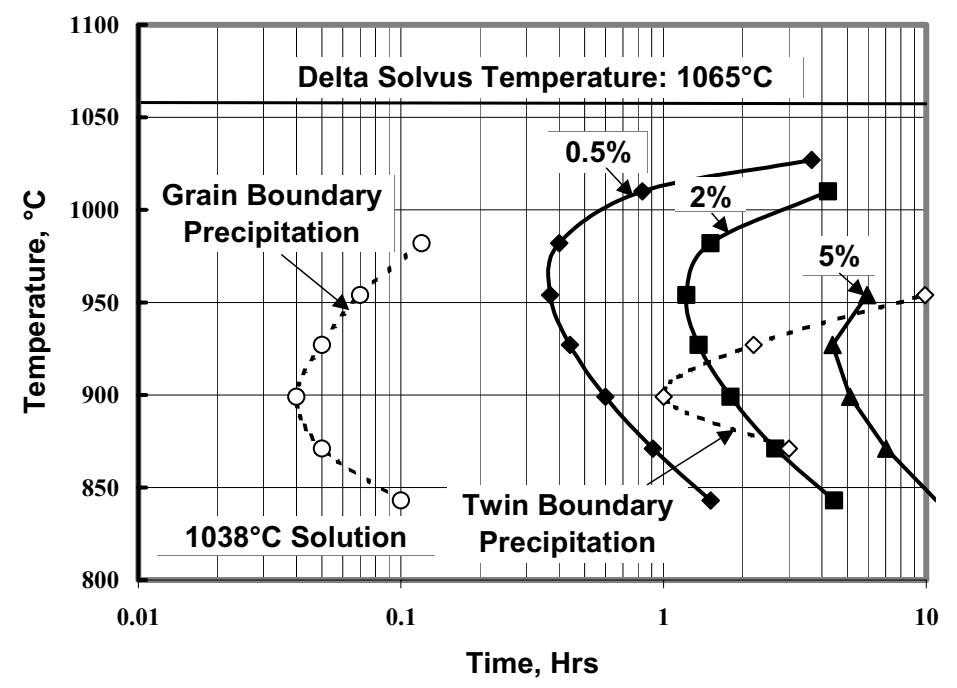

Figure 12. TTT Curves of Delta Phase Precipitation of Annealed Alloy 718Plus ${ }^{\mathrm{TM}}$ Determined by Modeling (Solid Line) and Experiment (Dashed Line).

An isothermal annealing study was carried out on alloy $718 \mathrm{Plus}$ plate hot-rolled at $1010^{\circ} \mathrm{C}$. The results are presented in Figure 13. Little $\delta$ phase existed in the initial as-rolled condition and extensive $\delta$ phase precipitation occurred during solution treatment. It seems that $\delta$ phase precipitation is structure-sensitive. It occurs first on grain boundaries, then on twin boundaries and eventually grain interiors. The nose temperature of $\delta$ phase precipitation is around $900-$ 
$950^{\circ} \mathrm{C}$. It seems that hot working accelerated $\delta$ phase precipitation at twin and intragranular locations. This result has an important practical meaning because, as stated below, massive $\delta$ phase formation will lead to significant degradation in mechanical properties of this alloy.

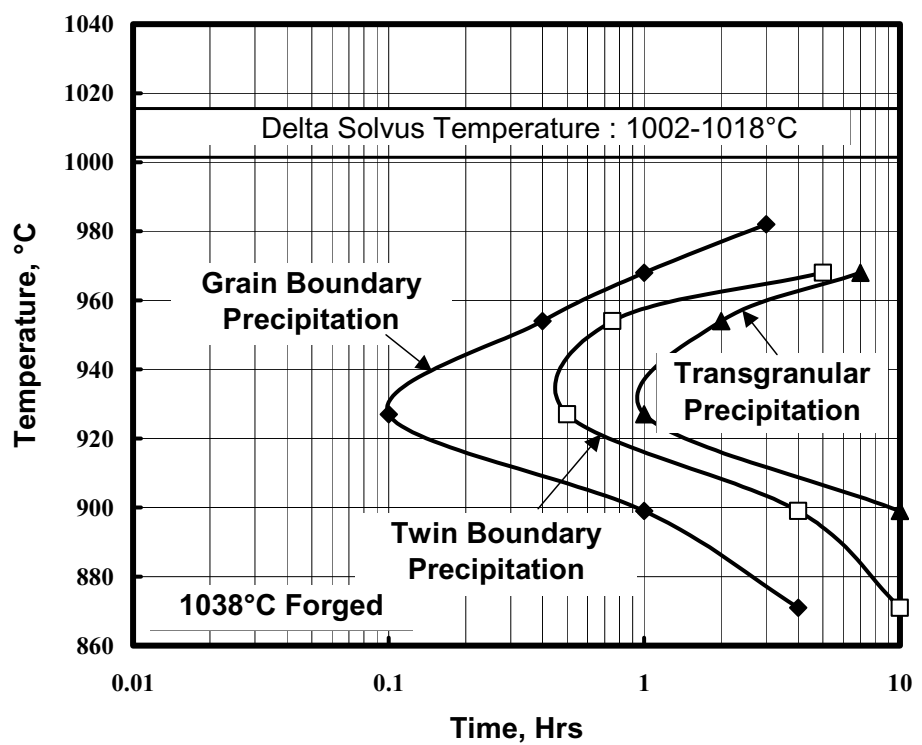

Figure 13. TTT Curve of Delta Phase Precipitation of As-Forged Alloy 718Plus ${ }^{\mathrm{TM}}$ Determined by Experiment.

Effect of $\delta$ Phase on Mechanical Properties of Alloy 718Plus

An extensive research program was initiated to compare the mechanical properties of alloys 718 , Waspaloy and 718Plus, especially to study the effect of $\delta$ phase morphology on mechanical properties of alloy 718Plus. The processing was tightly controlled to generate identical grain structure for all test materials. A special pre-solution was applied to form different morphologies of $\delta$ phase in alloy 718 Plus. The mechanical properties examined include strength, creep/stress rupture resistance and fatigue crack propagation characteristics. Table VIII lists partial results from this study.

Table VIII. Effect of $\delta$ Morphology on Mechanical Properties of Alloy 718Plus ${ }^{\mathrm{TM}}$ (All samples cut from $19 \mathrm{~mm}$ x $32 \mathrm{~mm}$ rolled rectangle bars with grain size ASTM 5-6)

\begin{tabular}{|c|c|c|c|c|c|c|c|c|}
\hline \multirow[b]{2}{*}{ Alloy } & \multirow[b]{2}{*}{$\delta$ Phase Morphology } & \multicolumn{4}{|c|}{ Tensile at $704^{\circ} \mathrm{C}$} & \multicolumn{3}{|c|}{$\begin{array}{c}\text { Creep at } 704^{\circ} \mathrm{C} / \\
483 \mathrm{MPa} \\
\end{array}$} \\
\hline & & $\begin{array}{l}\text { UTS } \\
\mathrm{MPa}\end{array}$ & $\begin{array}{l}\text { YS } \\
\mathrm{MPa}\end{array}$ & $\begin{array}{l}\mathrm{EL} \\
\%\end{array}$ & $\begin{array}{c}\text { RA } \\
\%\end{array}$ & $\begin{array}{l}\mathrm{t}_{0.1} \\
\mathrm{Hrs}\end{array}$ & $\begin{array}{l}\mathrm{t}_{0.2} \\
\mathrm{Hrs}\end{array}$ & $\begin{array}{c}\text { Creep } \\
\text { Rate } \\
\times 10^{-8} \mathrm{~s}^{-1}\end{array}$ \\
\hline 718 & Continuous GB Precipitation & 1022 & 953 & 17.9 & 24.3 & 50 & 122 & 4.1 \\
\hline Waspaloy & None & 1071 & 833 & 38.0 & 52.0 & 77 & 189 & 3.2 \\
\hline \multirow{4}{*}{ 718Plus } & Light GB Precipitation & 1155 & 951 & 15.3 & 16.0 & 186 & 385 & 0.12 \\
\hline & Continuous GB Precipitation & 1140 & 941 & 15.7 & 17.1 & 196 & 408 & 0.10 \\
\hline & $\begin{array}{c}\text { Extensive GB }+ \text { few } \\
\text { Transgranular Precipitation }\end{array}$ & 1132 & 943 & 15.6 & 15.3 & 147 & 351 & 0.17 \\
\hline & $\begin{array}{c}\text { Massive Transgranular } \\
\text { Precipitation }\end{array}$ & 1103 & 886 & 15.7 & 16.3 & 67 & 219 & 1.88 \\
\hline
\end{tabular}

Heat Treatment:

$718=954^{\circ} \mathrm{C} \times 1 \mathrm{hr}$, Air Cool, $718^{\circ} \mathrm{Cx} 8 \mathrm{Hrs}$, Furnace Cool at $55^{\circ} \mathrm{C} / \mathrm{h}$ to $621^{\circ} \mathrm{C}, 621^{\circ} \mathrm{Cx} 8 \mathrm{Hrs}$, Air Cool Waspaloy $=1018^{\circ} \mathrm{C} \mathrm{x} 1 \mathrm{hr}$, Water Quench, $843^{\circ} \mathrm{Cx} 4 \mathrm{Hrs}$, Air Cool, $788^{\circ} \mathrm{Fx} 16 \mathrm{Hrs}$, Air Cool

$718 \mathrm{Plus}=954^{\circ} \mathrm{C} \times 1 \mathrm{hr}$, Air Cool, $788^{\circ} \mathrm{C}$ x $2 \mathrm{Hrs}$, Furnace $\mathrm{Cool}$ at $55^{\circ} \mathrm{C} / \mathrm{h}$ to $650^{\circ} \mathrm{C}, 650^{\circ} \mathrm{C} \times 8 \mathrm{Hrs}, \mathrm{AC}$ 
The complete results of this study will be reported elsewhere. As one can see, alloy 718Plus does show strength and creep resistance superior to both 718 and Waspaloy, and $\delta$ phase morphology has a significant effect on its mechanical properties. The optimum morphology would be a small amount of nearly-continuous, short rod-shaped $\delta$ particles on the majority of grain boundaries. Mechanical properties significantly degraded once massive transgranular, long needle-like $\delta$ phase particle formation occurred. However, too few $\delta$ phase particles in this alloy may cause some other problems such as low hot ductility and stress rupture notch sensitivity.

Table IX shows the effect of solution temperature and time on the mechanical properties of alloy 718 Plus that has very few $\delta$ phase particles prior to solution treatment. Massive transgranular precipitation of $\delta$ phase particles occurred with long solution time at $954^{\circ} \mathrm{C}$, which led to reduction in both strength and rupture life. Solution at $982^{\circ} \mathrm{C}$ caused low ductility and especially notch break in stress rupture test, most likely due to lack of $\delta$ phase precipitation at this temperature.

Table IX. Effect of Solution Temperature and Time on Mechanical Properties of Alloy 718 Plus ${ }^{\mathrm{TM}}$

\begin{tabular}{|c|c|c|c|c|c|c|c|}
\hline \multirow{3}{*}{$\begin{array}{c}\text { Solution } \\
\text { Temperature }\end{array}$} & \multirow{2}{*}{$\begin{array}{c}\text { Solution } \\
\text { Time }\end{array}$} & \multicolumn{4}{|c|}{ Tensile at $704^{\circ} \mathrm{C}$} & \multicolumn{2}{c|}{$\begin{array}{c}\text { Stress Rupture at } \\
704^{\circ} \mathrm{C} / 552 \mathrm{MPa}\end{array}$} \\
\cline { 3 - 8 } & & $\begin{array}{c}\text { UTS } \\
\mathrm{MPa}\end{array}$ & $\begin{array}{c}\text { YS } \\
\mathrm{MPa}\end{array}$ & $\begin{array}{c}\text { EL } \\
\%\end{array}$ & $\begin{array}{c}\text { RA } \\
\%\end{array}$ & $\begin{array}{c}\text { Life } \\
\text { Hrs. }\end{array}$ & $\begin{array}{c}\text { EL } \\
\%\end{array}$ \\
\hline \multirow{2}{*}{$954^{\circ} \mathrm{C}$} & $1 \mathrm{hr}$. & 1174 & 1005 & 24.1 & 30.7 & 433.1 & 35.4 \\
\cline { 2 - 8 } & $3 \mathrm{hrs}$. & 1120 & 914 & 27.8 & 33.8 & 190.4 & 32.8 \\
\cline { 2 - 8 } & $4 \mathrm{hrs}$. & 1121 & 942 & 25.8 & 30.6 & 185.1 & 47.5 \\
\hline \multirow{2}{*}{$982^{\circ} \mathrm{C}$} & $1 \mathrm{hr}$. & 1108 & 863 & 12.4 & 14.1 & 1.9 & $\mathrm{NB}$ \\
\cline { 2 - 8 } & $3 \mathrm{hrs}$. & 969 & 745 & 8.3 & 12.5 & 0.3 & $\mathrm{NB}$ \\
\cline { 2 - 8 } & $4 \mathrm{hrs}$. & 958 & 739 & 9.1 & 15.3 & 0.3 & $\mathrm{NB}$ \\
\hline
\end{tabular}

Aging Treatment: $788^{\circ} \mathrm{C}$ x 2 Hrs. Furnace Cool at $55^{\circ} \mathrm{C} / \mathrm{hr}$. to $650^{\circ} \mathrm{C}$ x $8 \mathrm{Hrs}$., Air Cool

Figure 14(a) shows a grain boundary with ideal $\delta$ phase morphology, forming a so-called angular serrated grain boundary [12]. Figure 14(b) illustrates how $\delta$ phase particles on such a serrated grain boundary retards intergranular cracking, believed to be the mechanism responsible for notch breaks.

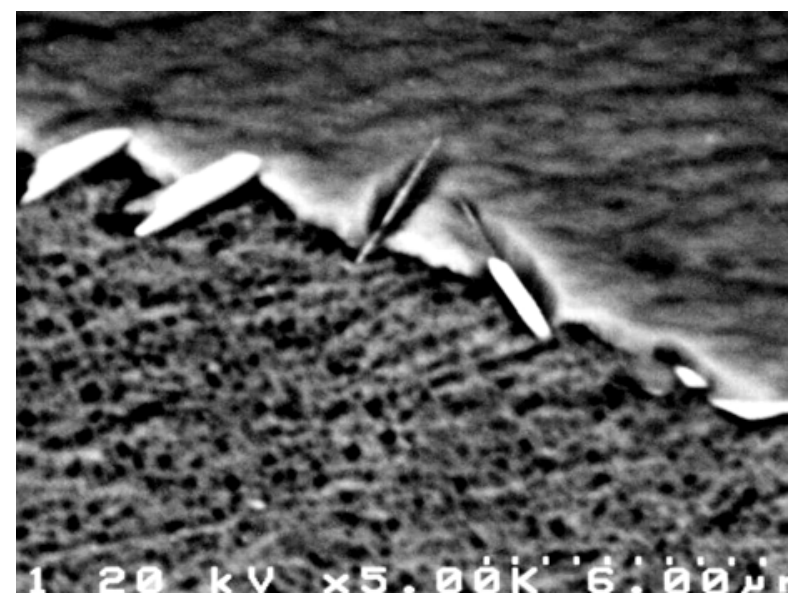

(a)

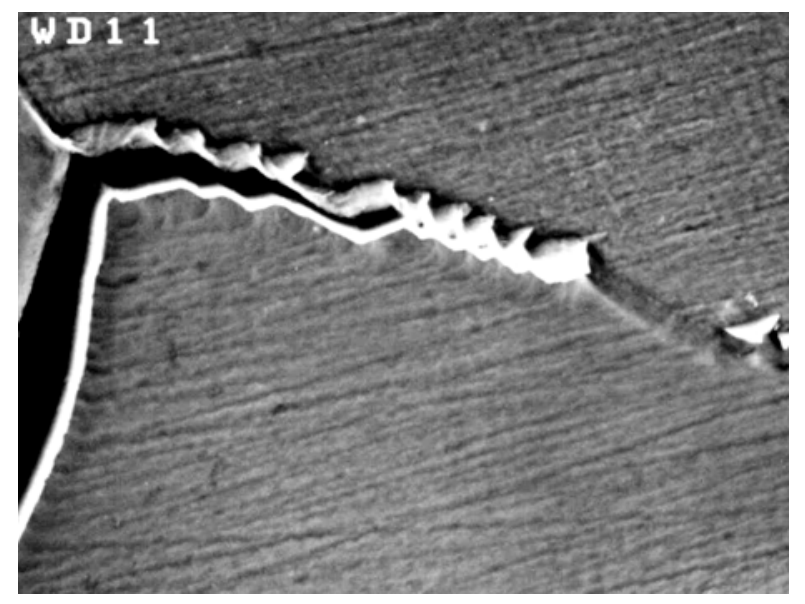

(b)

Figure 14. Interaction of Grain Boundary Delta Phase Particles with Intergranular Cracking: (a) Angular Serrated Grain Boundary and (b) Arrest of Intergranular Cracking at Serrated Grain Boundary. 


\section{Conclusions}

A significant amount of effort has gone into understanding the metallurgy of alloy 718Plus in order to be able to relate processing, structure and properties. Some of the conclusions drawn to date include the following:

1. Solidification characteristics of alloy 718Plus are very similar to those of alloy 718 . It should be possible to make alloy 718Plus ingot as large as that of alloy 718 .

2. The predominant precipitation hardening phase of this alloy is $\gamma^{\prime}$ phase containing high levels of $\mathrm{Nb}$ and $\mathrm{Al}$. The precipitation and growth rates of $\gamma^{\prime}$ phase in this alloy are slow in comparison with other $\gamma^{\prime}$ phase strengthening alloys such as Waspaloy, probably due to low diffusivity of $\mathrm{Nb}$.

3. Solution temperature and plastic deformation can drastically alter the kinetics of $\gamma^{\prime}$ phase precipitation.

4. Alloy 718Plus has high resistance to $\delta$ phase formation and therefore high thermal stability. The quantity and morphology of $\delta$ phase particles strongly affect the mechanical properties of this alloy. A small quantity of short, rod-shaped $\delta$ phase particles precipitated in a nearly continuous manner on grain boundaries can improve mechanical properties, especially preventing stress rupture notch sensitivity.

\section{References}

1. W.D. Cao, US Patent No.: 6,730.254 B2, 2004.

2. W.D. Cao and R.L. Kennedy, Superalloy 2004, ed. K.A. Green et al., TMS, 2004, 91-99.

3. R.L. Kennedy, W.D. Cao, T.D. Bayha and R. Jeniski, Niobium, High Temperature Applications, ed. Y.W. Kim et al., TMS, 2003, 11-22.

4. W.D. Cao and R.L. Kennedy, Acta Metallugica Sinica, Vol. 18, 2005, 39-46.

5. S. Ballantyne, Allvac Internal Report, 2004.

6. W.D. Cao, R.L. Kennedy and M.P. Willis, Superalloys 718, 625 and Various Derivatives, ed. E.A. Loria, TMS, 1991, 147-160.

7. G.K. Bouse, Superalloys 718 - Metallurgy and Applications, ed. E.A. Loria, TMS, 1989, 69-77.

8. M.J. Cieslak, G.A. Knorovsky, T.J. Headley and A.D. Romig, Jr, Superalloys 718 Metallurgy and Applications, ed. E.A. Loria, TMS, 1989, 59-68.

9. X.S. Xie, G.L. Wang, J.X. Dong, G.M. Xu, W.D. Cao and R.L. Kennedy, Superalloys 718, 625 and Various Derivatives, ed. E.A. Loria, TMS, 2005.

10. X.S. Xie, G.M. Xu, G.L. Wang, J.X. Dong, W.D. Cao and R.L. Kennedy, Superalloys 718, 625 and Various Derivatives, ed. E.A. Loria, TMS, 2005.

11. W.D. Cao and R.L. Kennedy, Superalloys 718, 625 and Various Derivatives, ed. E.A. Loria, TMS, 2005.

12. A.K. Koul and R. Thamburaj, Metall. Trans., Vol. 16A, 1985, p. 17. 